How to cite in Chicago: Alonso, Bruno. "Stoic Ethics as a Guide to the Political Life in Marcus Aurelius". Escritos 28, no. 61

\title{
Stoic Ethics as a Guide to the Political Life in Marcus Aurelius
}

\author{
La ética estóica como una guía para la vida política en Marco Aurelio
}

Bruno Alonso ${ }^{1}$

\begin{abstract}
Marcus Aurelius reigned from 161 A.D. to 180 A.D., and he ranks among the most successful emperors of the antonine dynasty. The success of his administration may be attributed to his philosopher personality and, more than that, to his stoic character. Meditations presents thoughts of a stoicism devotee, which reflects in moments of intimacy on the challenges that he faced throughout his life as an emperor. It is in the practice of the ethical precepts of stoicism that he finds his refuge. The text consists of a series of spiritual exercises which reaffirm the indifference to pleasures, contempt for fame, detachment from riches and abnegation for political power. This paper is a study of Meditations, and its main purpose is to elucidate how the stoic way of life is incorporated in the figure of the philosopher emperor; this, as a military function, as he was a commander of the Roman army in the war against the Nordics, where political virtue was tested. Amid the chaos of an insane struggle for the survival of Rome, he found in stoicism a precious source of inspiration. Marcus Aurelius was not dazzled by the cult of the emperor's personality; he acted for the natural right to freedom and guided his political actions for the common good. His stoic perseverance reveals itself in a harmonious conduct with the city, the rational and cosmic organism from which the emperor is a simple part.
\end{abstract}

Keywords: Marcus Aurelius; Meditations; Philosophy; Ethics; Stoicism; Antiquity; Rome; Politics.

\section{RESUMEN}

Marco Aurelio reinó desde el 161 d.C. hasta el 180 d.C. y se encuentra entre los emperadores más exitosos de la dinastía antonina. El éxito de su administración se puede atribuir a su personalidad de filósofo y, más que eso, a su carácter estoico. Meditaciones presenta los pensamientos de un devoto del estoicismo, que reflexiona en los momentos de intimidad sobre los desafíos enfrentados en su vida como emperador. Es en la práctica de los preceptos éticos del estoicismo donde encuentra su refugio. El texto contiene una serie de ejercicios espirituales que reafirman la indiferencia por los placeres, el desprecio por la fama, el desapego de las riquezas y la abnegación por el poder político. Este artículo es un estudio de Meditaciones, el cual tiene como propósito dilucidar cómo se incorpora la forma de vida estoica en la figura del emperador filósofo. Pero es en la función militar, como comandante del ejército romano en la guerra contra los nórdicos, donde se pone a prueba su virtud política; así,

1 Master in Philosophy by the Universidade Federal Fluminense (PFI-UFF), Brazil, and PhD student in Philosophy at the Universidade Federal do Rio de Janeiro (PPGF-UFRJ), Brazil. E-mail: brunoalonso@id.uff.br 
en medio del caos de una lucha insana por la supervivencia de Roma, encontró en el estoicismo una preciosa fuente de inspiración. Marco Aurelio no se deslumbró por el culto a la personalidad del emperador, actuó a favor del derecho natural a la libertad y orientó sus acciones políticas en favor del bien común. Su perseverancia estoica se reveló en una conducta armoniosa con la ciudad, el organismo racional y cósmico del cual el emperador es una sencilla parte.

Palabras clave: Marco Aurelio; Meditaciones; Filosofía; Etica; Estoicismo; Antigüedad; Roma; Política.

\section{Introduction to Marcus Aurelius' Meditations}

B efore getting precisely into the general subject, an interpretation of Meditations is necessary, with an approach directed to the elements related to stoicism, which dominates great part of the text. This is, first of all, in order to stress the importance of stoicism as a pedagogical device in the intellectual education of Marcus Aurelius (121-180 AD), and then, appreciate the idea that his dedication to philosophy was a decisive ingredient to his success as emperor of Rome.

Meditations is a set of texts which the Roman emperor Marcus Aurelius wrote to himself. ${ }^{2}$ The style of the text is some sort of monologue, a first person speech, in which the author seeks to overcome the vain thoughts that haunt his consciousness. It can be defined as a series of spiritual exercises, according to the definition of Pierre Hadot, which work as a manual permeated under the ethical precepts of stoicism, subtle synthesis and reveal a viable lifestyle to the realization of virtue. They act as writings to remember ( $\dot{\pi} \pi \mu \nu \eta \dot{\eta} \mu \alpha \alpha$ ) the philosophical teachings, which work as a place of haven, a timeless message, that allow the author to refuge into himself, indifferent to adversities and to handle the incidents of fate: $\dot{\xi} \xi$ óv, $\tilde{\eta} \varsigma$

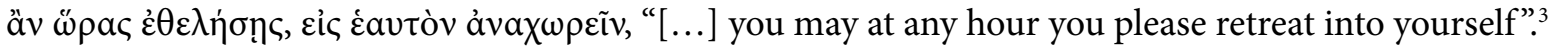

Marcus Aurelius wrote to himself so that he could return to his fundamental philosophical questions and remember them again. A fundamental question that appears in several passages of Meditations is the challenge of dealing with destructive emotions ( $\pi \dot{\alpha} \theta$ oc), which affect mental sanity in a negative way:

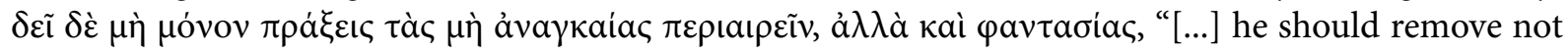
actions merely that are unnecessary, but imaginations also". The spiritual exercise (ä $\sigma \kappa \eta \sigma ı)$ ) is directed to the improvement of what Marcus Aurelius calls $\dot{\gamma} \gamma \varepsilon \mu$ oviкóv (the reason that commands the inner self), that can be understood as mind, counsciousness, judgement, understanding, and so on.

Within stoicism, both the hellenistic and Roman, there is an unwavering belief that mind is impenetrable

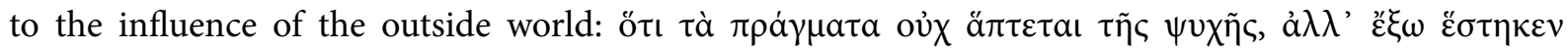

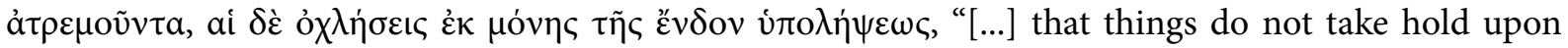
the mind, but stand without unmoved, and that disturbances come only from the judgement within". Everything we experience is not consequence of the immediate impressions of the senses, because there

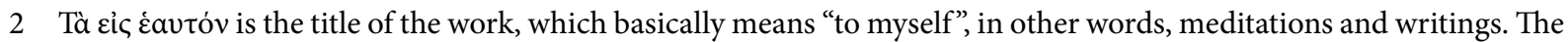
purpose of these is to open the way for the author to correct his thoughts and understand the things that affect him.

3 Marcus Aurelius, Meditations, 47.

4 Marcus Aurelius, Meditations, 55.

5 Marcus Aurelius, Meditations, 49. 
is no direct correlation with the external events. Opinions are the work of assent; these are originated in the inner judgement made from the experiences.

On the other hand, the soul is not directly affected by the passions of the outside world. Marcus Aurelius seeked through the stoic precepts to exercise the clarity of judgement, to improve his ability to grant correctly about the objects that touched him. This conception has its origin in the philosophy of Epictetus, a Roman stoic whose doctrine was extremely influential in Marcus Aurelius' education. ${ }^{6}$ Marcus Aurelius was his student, and Meditations was strongly inspired by the teachings of his master. It is provocative to imagine that a Roman emperor considers himself a disciple of a man who spent most of his life living as a slave. In this relationship, the opposites are in absolute consonance and harmony, the same way of living, providing a single ideal, for two men in completely different and antagonistic conditions.

The main idea in Meditations is that the individual reason must be constantly exercised, in order to obtain full control over the impulses and desires. Another essential point of the philosophy of Epictetus

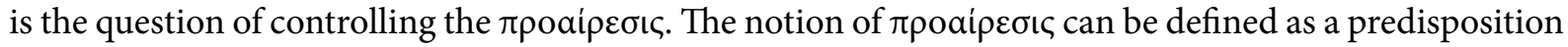
to act and think in a determined way, a constant act of will that establishes the criteria that regulates and motivates choices. For Epictetus, this question is mainly about the recognition that the man deals only with two categories of things: those that are some kind of burden and those that do not depend on him. The human being can control the opinion and the discernment of dealing with desires and impulses; other things, such as health, wealth and fame, are goods that escape choices:

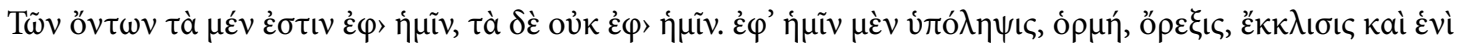

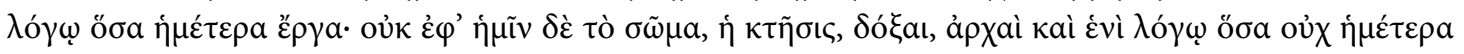
हैрүa.

There are things which are within our power, and there are things which are beyond our power. Within our power are opinion, aim, desire, aversion, and, in one word, whatever affairs are our own. Beyond our power are body, property, reputation, office, and, in one word, whatever are not properly our own affairs. ${ }^{7}$

Even if the desire to possess a certain object persists or the impulse to act hastily, the power of re-

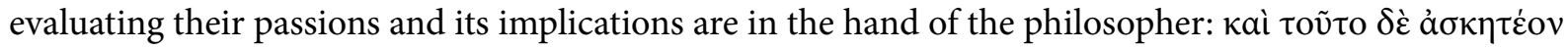

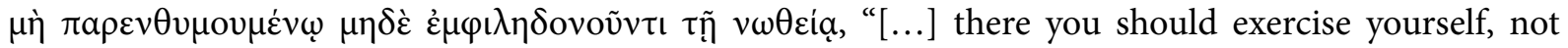

6 Epictetus weaves a relationship between the principles of the soul ( $\psi v x \dot{\eta})$ which rule life with the three branches

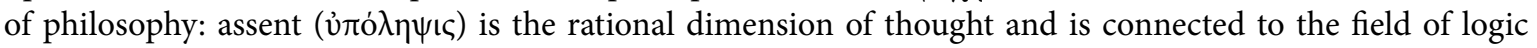

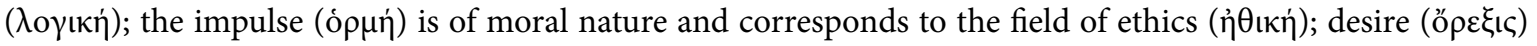

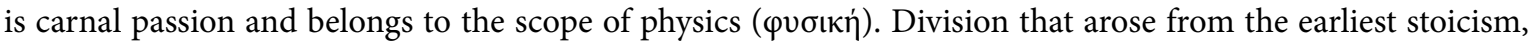

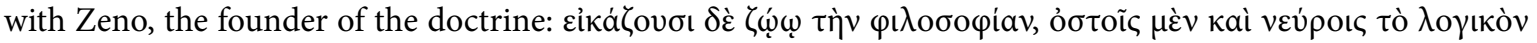

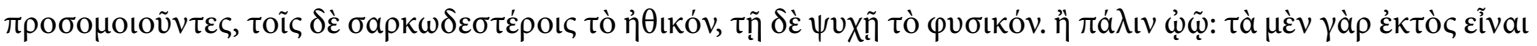

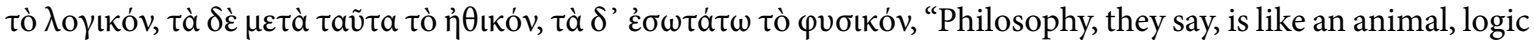
corresponding to the bones and sinews, ethics to the fleshy parts, physics to the soul. Another simile they use is that of an egg: the shell is logic, next comes the white, ethics, and the yolk in the centre is physics" (Diogenes Laertius, Lives of eminent philosophers, 151).

7 Epictetus, The Enchiridion, 215. 
disregarding your faults nor find satisfaction in your dullness". Through an exercise of assent, the philosopher must decompose the objects that afflict him, to see them in their true nakedness. ${ }^{9}$

\section{Spiritual exercises: the way to overcome vain thoughts and live virtuously}

In Marcus Aurelius' stoicism, there is a concern about the pragmatic aspect of philosophy, observed by the

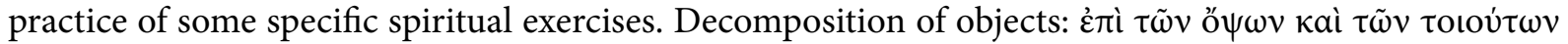

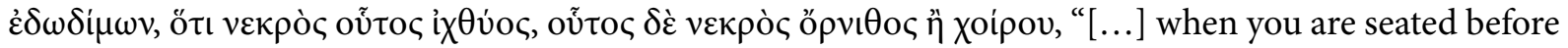
delicacies and choice foods, to impress upon your imagination that this is the dead body of a fish, that

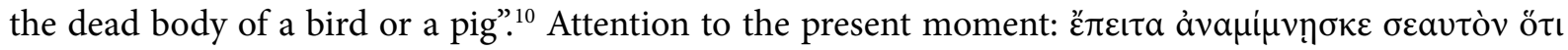

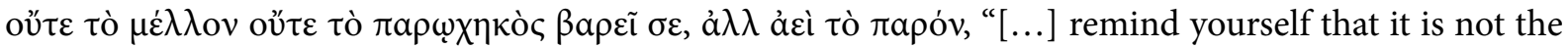
future or the past that weighs heavy upon you, but always the present". ${ }^{11}$ Meditation on death: $\Omega \varsigma \eta$ " $\delta \eta$

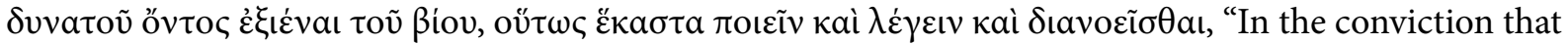
it is possible you may depart from life at once, act and speak and think in every case accordingly". ${ }^{12}$ And

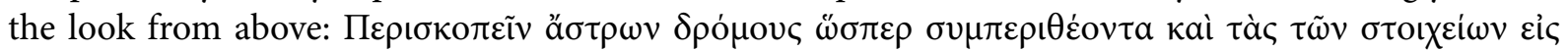

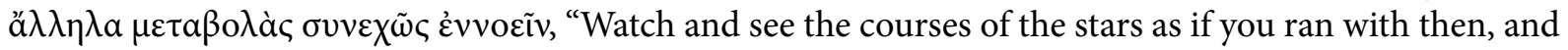
continually dwell in mind upon the changes of the elements into one another". ${ }^{13}$

The above, besides the fundamental ethic principle of living according to the nature that belongs to stoicism since its origin with Zeno. Such meditative practices are directed to the purpose of ascending to

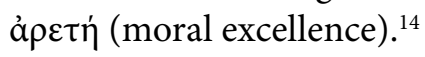

8 Marcus Aurelius, Meditations, 67.

9 On a first cognitive level, there are sensations ( $a$ İ $\sigma \eta \eta \sigma \varsigma)$. Through synesthesia, which combines various sensations

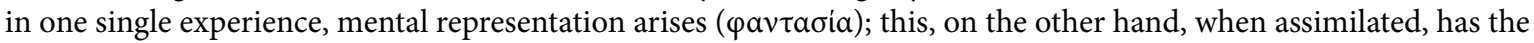
power to transform itself into a mental image ( $\varphi \breve{a} v \tau \breve{\alpha} \sigma \mu \breve{\alpha})$. Erroneous impressions that negatively incite impulses and

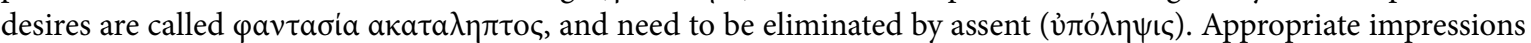

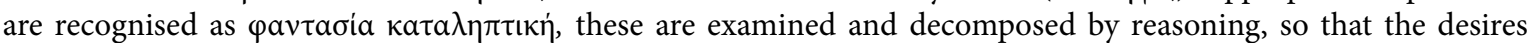

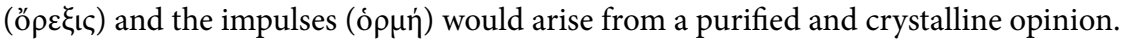

10 Marcus Aurelius, Meditations, 83.

11 Marcus Aurelius, Meditations, 128.

12 Marcus Aurelius, Meditations, 31.

13 Marcus Aurelius, Meditations, 109.

14 Cicero addresses a recurring question in classical philosophy, the mystery in relation to the nature of virtue: Nam, sive honestum solum bonum est, ut Stoicis placet, sive, quod honestum est, id ita summum bonum est, quem ad modum Peripateticis vestris videtur, ut omnia ex altera parte collocata vix minimi momenti instar habeant, dubitandum non est, quin numquam possit utilitas cum honestate contendere. Itaque accepimus Socratem exsecrari solitum eos, qui primum haec natura cohaerentia opinione distraxissent. Cui quidem ita sunt Stoici assensi, ut et, quicquid honestum esset, id utile esse censerent nec utile quicquam, quod non honestum, "For whether moral goodness is the only good, as the stoics believe, or whether, as your peripatetics think, moral goodness is in so far the highest good that everything else gathered together into the opposing scale would have scarcely the slightest weight, it is beyond question that expediency can never conflict with moral rectitude. And so, we have heard, Socrates used to pronounce a curse upon those who first drew a conceptual distinction between things naturally inseparable. With this doctrine the stoics are in agreement in so far as they maintain that if anything is morally right, it is expedient, and if anything is not morally 
Unlike Seneca, who represents a more moderate strand of stoicism, Marcus Aurelius starts from a more radical approach, not sympathetic to Epicurus' ideas. He does not open space for the appreciation of pleasure, disowning the epicurean parsimonious hedonism and respective notion that virtue succeeds natural and necessary pleasures.

Lattention (prorochè) est l'attitude spirituelle fondamentale du stoïcien. C'est une vigilance et une présence d'esprit continuelles, une conscience de soi toujours éveillée, une tension constante de l'esprit. ${ }^{15}$

When addressing the topic of practicing spiritual exercises in the context of hellenistic and Roman philosophy, Hadot emphasized a practice that characterizes stoicism: tóvoc, that is, the constant exercise of tension in the spirit. In Marcus Aurelius' Meditations, there were several examples of practices of such exercises, with a touch of sophistication and a strictly determined pragmatic sense. The type of exercise

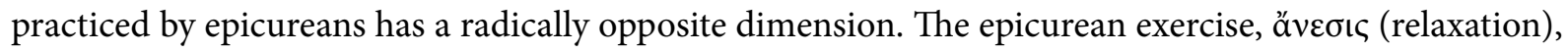
recommends a pleasant posture, away from the disturbances of the soul. In stoicism, on the other hand, the orientation prevails to maintain an active posture, to occupy the mind with the imminence of misfortunes, and thus, be prepared to remain indifferent to the injunctions of destiny.

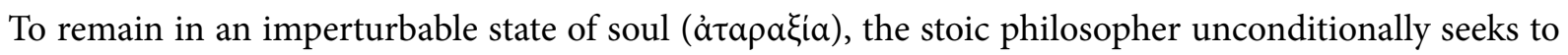

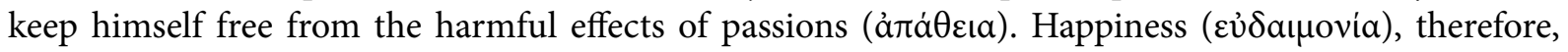
results from the recognition that everything that does not depend directly on the man's actions is absolutely indifferent ( $\dot{\alpha} \delta \dot{\alpha} \varphi o \rho \alpha)$. Also, among the indifferent, there are those who are preferable

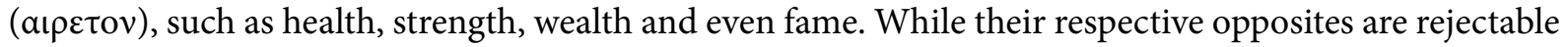
-although they only have relative value-, these are illness, weakness, infamy and poverty. This distinction provides a greater malleability to stoic ethics, an ascetic doctrine known for the rigor of convictions and by the model of wisdom idealized in an unachievable horizon. However, Marcus Aurelius is categorical in conceiving the indifferent as devoid of any value; there is only one thing that depends on the conduct

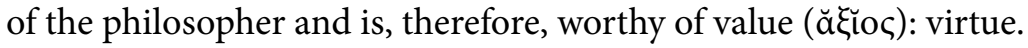

What are music and dance? Music is made of mere sounds, notes are produced by a given musical instrument, which taken alone, are no more than insipid noises. Dance is nothing more than a series of body movements passively driven by the influence of music. What about the gladiator games? A brutal theater where slaves are forced to kill each other for the sake of morbid pleasure of an audience of ignorants. What about the feasts? A dish considered exquisite, made with fish or other tasty meats, it is nothing more than the corpse of an animal. Wine is reduced to a thick liquid extracted from a fruit.

right, it is not expedient" (Cicero, De Officiis, 279-281). Based on the platonic conception of the four cardinal virtues

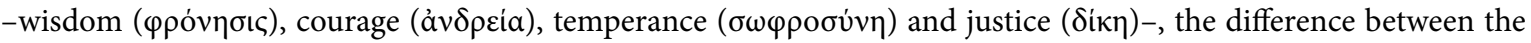
two philosophical currents occurs when understanding the modus operandi; i.e., the stoics hold the idea that it is impossible to achieve excellence without simultaneously conquering the four cardinal virtues, the peripatetics defend the idea that there is no need relationship between the four virtues in a way that it is possible to exercise at least one of them without possessing the others. In De Officiis, Cicero invoked this discussion, attempting to overcome such a theoretical divergence in favor of the stoics position, to defend the idea that individual convenience is strictly subordinated to the collective moral good.

15 Hadot, Exercices Spirituels et Philosophie Antique, 26. 


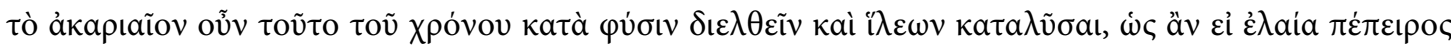

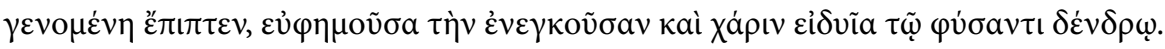

Therefore make your passage through this span of time in obedience to nature and gladly lay down your life, as an olive, when ripe, might fall, blessing her who bare it and the grateful to the tree which gave it life. ${ }^{16}$

What about the time of life? Existance has a tiny duration compared to temporal infinity, which is immense in relation to the short time the human being has in life. The only thing experienced in life is the present time. Past concerns something which has already happened, and the future is the projection of a time that is yet to come. Past and future, strictly speaking, do not exist; the only time lost at the

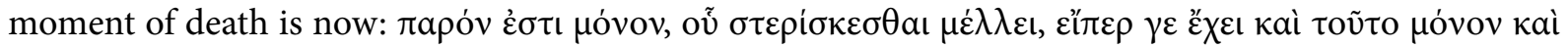

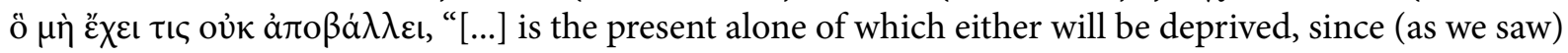
this is all he has and a man does not lose what he has not got". ${ }^{17}$ The exercise of attention to the present moment leads to indifference to death: there is no difference between dying young or old, because both leave only the present behind. When looking at earthly life, casting a glance from above, it becomes clear how insignificant human existence is. Even the Roman empire, seen from above, is just a piece of land.

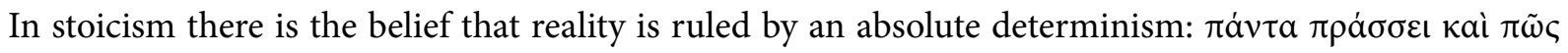

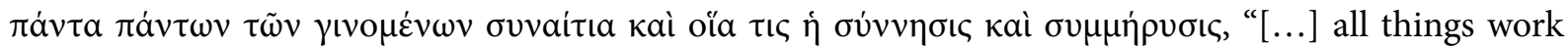
together to cause all that comes to pass, and their wonderful web and texture". ${ }^{18}$ All events happen by the force of fate. Thus, the philosopher needs to accept the events that are outside their purview: $\mu \eta \delta \dot{\varepsilon} v$ $\pi \varepsilon \rho \mu \varepsilon \dot{\varepsilon} v \omega v \mu \eta \delta \dot{\varepsilon}$ $\Phi \varepsilon \dot{v} \gamma \omega \nu$, "[...] expecting nothing and avoiding nothing". ${ }^{19}$ Cosmos is ruled by seminal

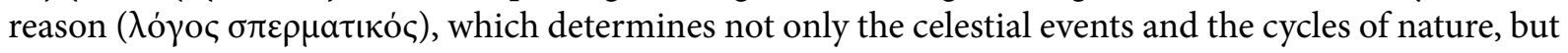
also the destiny of men. Meditations revive the precept that living, according to nature, depends on the laws of reason; and there is nothing evil about being natural, because everything that happens according to nature is an event arising from the force of necessity.

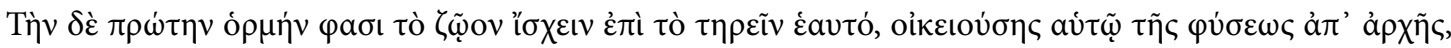

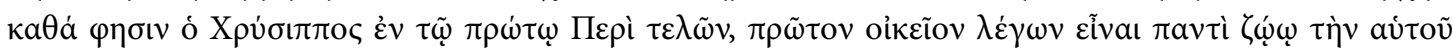

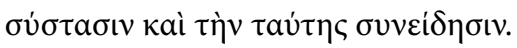

An animal's first impulse, say the stoics, is to selfpreservation, because nature from the outset endears it to itself, as Chrysippus affirms in the first book of his work on ends: his words are, "The dearest thing to every animal is its own constitution and its consciousness thereof". ${ }^{20}$

On the other hand, Zeno's classic stoicism is founded on the conception that the primordial impetus,

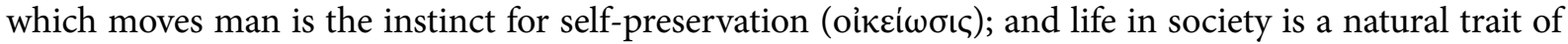

16 Marcus Aurelius, Meditations, 62.

17 Marcus Aurelius, Meditations, 33.

18 Marcus Aurelius, Meditations, 60.

19 Marcus Aurelius, Meditations, 44.

20 Diogenes Laertius, Lives of eminent philosophers, 193. 
human existence, necessary to guarantee the survival of each individual. This is why the stoics profess that the philosopher should dedicate to politics, when they have the minimal necessary conditions to do so.

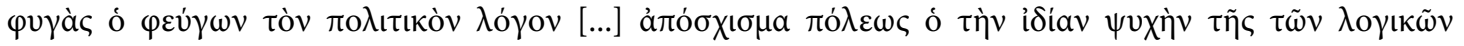

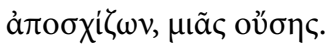

A fugitive is he who away from the reasonable law of this city; [...] a fragment cut off from the city, he who cuts off his own soul from the soul of reasonable creatures, which is one. ${ }^{21}$

As Marcus Aurelius states, the one who does not aggregate to community life is a severed limb, not only for the city, but for nature and cosmos; and the man who, in his right mind, ignores the collective organism in which he is inserted, is a severed limb of universal reason. Thus, human reason is the mirror of a higher reality, a microcosm within the macrocosm, once the individuals integrate universal reason. ${ }^{22}$

Living according to nature, the stoic maxim that inspires Marcus Aurelius, recommends that virtuous

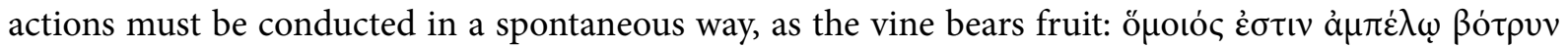

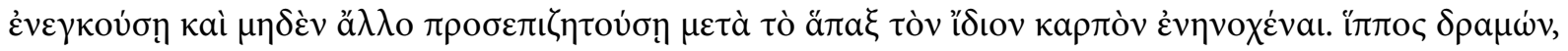

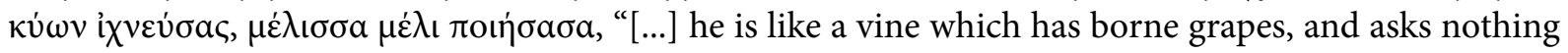
more when once it has borne its appropriate fruit. A horse runs, a hound tracks, bees make honey". ${ }^{23}$ Like a tree that bears fruit, which corresponds to its own nature, man performs good deeds because it is his nature to act for the common good.

What is fame and why does it exert an enormous fascination on most men? Everything disappears in a short period of time. Fame is no more but the fickle opinion of the crowd, which is soon extinguished, aphasic, in the void of repercussion. The philosopher must remain indifferent to the laurels of fame;

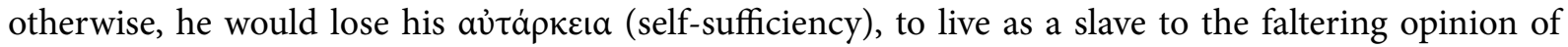
others. The same can be told about the riches: the material goods are expendable, and basic needs can be met with very little. An existence dedicated to earning wealth and obtaining possessions is a life wasted on superfluous things, as well as the craving for power, an unhealthy ambition whose aim is only to dispose of perfidious means to manipulate other people, to gain some advantage from this. This is a behavior totally contrary to the true purpose of political activity.

21 Marcus Aurelius, Meditations, 56-57.

22 Free yourself from the dominion of passions is a requirement for the stoic to be attuned with cosmic reason. Gagin referred to amor fati as an encouragement for the emperor Marcus Aurelius, a confomity posture in relation to fate, which propitiates the wise to resist their own passions and not to be shaken by the intrusion of the passions of others: "La pasión que los estoicos quisieran eliminar es el umbral que posibilita y ocasiona los intentos de probar(se) y de efectuar la virtud. No olvidamos que, en el campo de lo político, de la mayoría de los hombres, únicamente el sabio viviría en perfecta consonancia con la razón cósmica y con la suya propia, en un amor fati. Marco Aurelio en tanto que emperador, pero sobre todo en tanto que hombre, deberá para sí preservar la integridad de su yo, de cara a sus pasiones, como también a las ajenas" (Gagin, El yo y los otros: la estilización de sí y de las figuras al margen de la filosofía en las Meditaciones de Marco Aurelio, 100).

23 Marcus Aurelius, Meditations, 67. 


\section{The stoic emperor}

Marcus Aurelius began to write Meditations when he was campaigning in the Danube, when he was the head of the Roman army against the barbarian invaders. After expelling the German tribes that threatened the borders of the empire and manage to turn the tide of events in favor of Rome, the fame of the emperor's grew exponentially among the Roman citizens. Birley pointed out the firmness of the emperor in command of military opperations; Marcus Aurelius did not act out of fear of unpopularity or, at least, the yearning to be adulated by the troops. ${ }^{24}$ As a typical stoic, Marcus Aurelius was fully aware of the dangers that the laurels of victory concealed:

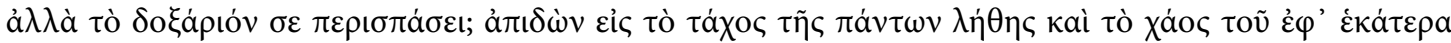

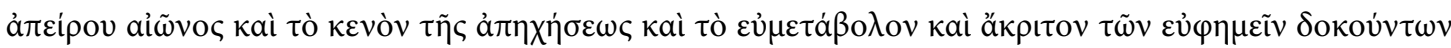

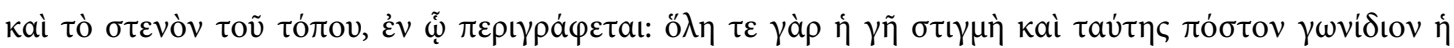

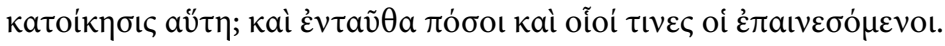

Well, then, shall mere glory distract you? Look at the swiftness of the oblivion of all men; the gulf of endless time, behind and before; the hollowness of applause, the fickleness and folly of those who seem to speak well of you, and the narrow room in which it is confined. This should make you pause. For the entire Earth is a point in space, and how small a corner thereof is this your dwelling place, and how few and how paltry those who will sing your praises here! $!^{25}$

It is no wonder that indifference to glory is one of the most recurrent themes in his writings. A man in his condition had a vast territory under his rule, and his decisions would interfere directly in the life of his subjects. Marcus Aurelius prevented himself by not giving in to the vulgar opinion of his own divinization, removing the image of the new Caesar from himself, so as not to become susceptible to vanity and incurring the vice of spreading the cult to the image of the emperor.

Marcus Aurelius is not deceived by the aristocratic belief in a pretentious superiority. Stoicism is a cosmopolitan doctrine, which describes men as part of a single nature, united equally by reason, whether they are slaves or free, women or men, barbarian or Roman. Noyen argued that Marcus Aurelius undertook significant reforms in Roman law, especially in relation to the social status of slaves, who are now recognized as subjects endowed with rights. ${ }^{26}$ Nascimento and Matos brought a series of historical data extracted from the Digesta of Justinian, records of legal decisions in which Marcus Aurelius decreed

24 After his first victory against the barbarians, he did not let himself be seduced by the outcry of the soldiers, and denied the request for the reward for the conquest: "After the first victory he had won in person, although he accepted the salutation as emperator, he refused the troops' request for a donative, 'saying that whatever they got from him over and above their regular pay would be wrung from the blood of their parents and families; as for the fate of the sovereignty, God alone could determine that. So temperately and firmly did he rule that even when engaged in so many and so great wars, he never did anything unworthy by way of flattery or as the result of fear" (Birley, Marcus Aurelius: A Biography, 169).

25 Marcus Aurelius, Meditations, 48-49.

26 Cf. Noyen, Marcus Aurelius, the Greatest practician of stoicism, 380. 
the liberation of some slaves. ${ }^{27}$ The stoic emperor, as judge and legislator, acted under the aegis of natural right to freedom. Stoicism is the moral ingredient which prompted Marcus Aurelius not to relegate his legal decisions to a cold and artificial reading of the letter of the law.

The claim for non-tragic living appears frequently along with the great names of the past. As all events were and will always be the same, all the heroes of the past were engulfed by the course of time and all the heroes of the future will be engulfed as well. It is always the same stage where the play is always repeated. Therefore, it would be an error to identify oneself with a name as if it were something special, or even with one's role in life. As Marcus Aurelius says, not to be caesarified (VI, 30), not to play the emperor according to the role models of the great emperors, if they played along, not to consider oneself exceptional when one happens to be an Alexander or an Augustus. Even an emperor is no more and no less than a reasonable being, a human being. Even Alexander perished and is forgotten, and after every conflagration plays his part: again and again an Alexander rules and dies. ${ }^{28}$

On the other hand, Wolf interpreted Meditations with the expression of an emperor who recognizes himself in a political leadership, in the horizon of an absolutely anti-tragic existence. The ethic principle

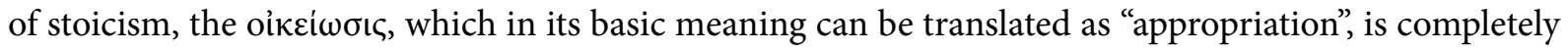
averse to the condition of alienation designing a tragic character. The tragedy lies precisely in perplexity and resistance to the events of destiny. Why entertain gradiose expectations if the world is an eternal return? The characters repeat themselves, the same way, as a small part of a cosmic cycle. For this author, there is nothing tragic, no event is unexpected, for all things are conceived by the force of nature.

Even Alexander and Augustus were simple men, fated to be forgotten. Marcus Aurelius keeps a sober image of himself, detached from ambition blinded by prestige, which motivated the decay of some Roman emperors of the past. It is easy to remember some examples of these men who were ruined by the cult of their own image, because they got attached blindly to fame and forgot the real purpose of their high position..$^{29}$ Even when possessing all the riches the ancient world could offer, Marcus Aurelius lived a simple life, detached from the pleasures and privileges of money and power.

La culture de l'esprit lui est devenue indifférente, seule compte à ses yeux celle de lâme. C'est alors qu'il se souvient que sa mère lui avait transmis le goût de la simplicité et <<léloignement de la manière de vivre des riches $>>$. Cer éloignement pouvait être celui d'un aristocrate envers l'argent, l'argent qu'il a reçu à profusion, ou d'une âme éprise d’autérité. Il refuse le décorum de sa fonction (les lampadaires), il voudrait $<<$ vivre comme un particulier $>>-$ mais pas comme <<un patricien sans coeur $>>$. A-t-il donc une fibre sociale, veut-il ne pas se couper de son peuple? Ce nest apparemment pas son souci. Il est sobre par nature et par tradition familiale - d'où son choix de philosophie. On ne voit pas chez lui la contrepartie de sympathie à l'égard des pauvres. La charité n’est pas l'affaire des stoïciens. ${ }^{30}$

27 Cf. Nascimento and Matos, Stoicism and Roman law: the rescripts of emperor Marcus Aurelius on family law and the law of liberty, 5-9.

28 Wolf, Marcus Aurelius and non-tragic living, 194-195.

29 Caligula and Nero are certainly on the list of the worst examples of emperors in the history of Rome. And due to the misfortune of fate, Marcus Aurelius successor and son, Commodus, ruled with iron fists, excessively self-centered, created a kind of cult deifying his own figure. It turned out to be exactly the opposite of the example set by his father.

30 Fontaine, Marc Aurèle, 42-43. 
Moreover, Fontaine defined him as a distinguished politician who guided life through moderation and the common good. Stoicism is a doctrine underestimated by ascetic character, above all, by the belief that the philosopher can live indifferent to the temptations of the flesh and to the worst misfortunes of fate. Marcus Aurelius embodies the ideal with mastery; that is why Politics, for him, is a phenomenon which cannot be dissociated from ethics. He was an emperor who faced not only the inner challenge of keeping imune to passions and dedicated to the public good, but the arduous duty to help fellow citizens in their misguided judgments and guide them on the path of excellence. ${ }^{31}$

Donc, pas d'utopie, mais une vue réaliste des possibilités et des limites de la naturc humaine et une politique ne visant que des objeclifs précis et limités. Et, par ailleurs, l'empereur-philosophe rejette Ioule pulilique de prestige. Il faut faire ce que la raison impose de faire [...] Pour Marc Aurèle, la philosophie ne propose donc pas de programme politique. Mais il attend d’elle qu’elle le forme, quelle le prépare, grâce aux exercices spirituels qu'il accomplit, à mener son action politique dans un certain esprit, selon un certain style. Ce qui importe, c'est moins ce qu'on fait que la manière dont on le fait. Au fond, il n'y a de politique quéthique. Elle consiste avant tout dans cette discipline de l'action que nous avons analysée et qui implique essentiellement service de la communauté humaine. dévouement à autrui et esprit de justice. La politique, comme ln discipline de l'action, ne peut d’ailleurs se séparer de ces grande perspectives cosmiques ct humaines que nous ouvre la reconnaislance d'une universalité transcendante, la Raison et la Nature, qui, par son accord avec elle-même, fonde à la fois l'amour des hommes les uns pour les autres et l'amour des hommes pour le Tout dont ils sont les parties. ${ }^{32}$

Therefore, Hadot identified a strict ethical discipline in the political life of Marcus Aurelius, where spiritual exercises perform a function of refuge, and the emperor can immerse within himself. Meditations are a group of exercises to preserve the psychic integrity of his author, who intends to overcome the selfishness of ordinary ambitions to, this way, practice spontaneous love to men and cultivate zeal for the public thing. It is always in the hands of the ruler to make his own decisions, which must be guided by the universal good, i.e., by the natural and cosmic perspective. Marcus Aurelius makes an analogy of the

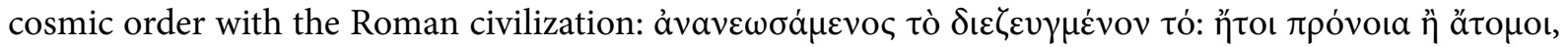

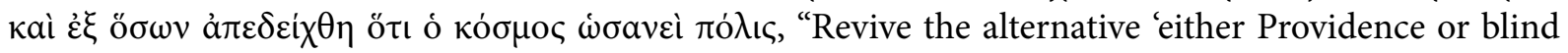

31 According to Lombardini, Marcus Aurelius's political virtue reveals itself in the ability of exercising tolerance with the divergent and, mainly, in the ethic duty of instructing the companions who live in the blindness of ignorance: “[...] Marcus often treats toleration as something we extend not simply to those who hold opinions that differ from our own, but to those who hold incorrect opinions. In this sense, toleration is figured as a vertical practice: student towards pupil, philosopher towards the uneducated, emperor towards subject. It is this last relationship, of course, with which Marcus was intimately familiar, and part of his concern in the Meditations is reflecting on how it is that

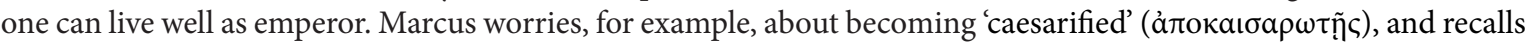
the example of Antoninus Pius as a prophylactic in this context. Yet Marcus also writes the Meditations in order to keep at hand ( $\pi \rho$ ó $\chi \varepsilon\llcorner\rho)$ those principles he believed were necessary for living well. In this sense, he writes as someone who is committed to stoic principles, and by virtue of inhabiting that role, he ought to teach and instruct those who, on account of their mistaken judgments, are unable to live well" (Lombardini, Stoicism and the virtue of toleration, 661-662).

32 Hadot, La Citadelle Intérieure: Introduction aux Pensées de Marc Aurèle, 323-325. 
atoms', and the many proofs that the universe is a kind of commonwealth".33 The project of the universal city idealized by Zeno, the founder of stoicism, becomes, finally, reality under his command. ${ }^{34}$

Marcus Aurelius faced an extremely difficult situation when he needed to act in two fronts of battle: in Asia, to defend his borders which were being invaded by the Parthians, and in the north of Europe, where empire expanded beyond the Danube. The latter, no doubt, was what most marked the military life of the philosopher emperor; the hard war against the barbarians, was not something he accomplished for the need to expand the territory, conquer new subjects and gain prestige. Not that he considered them inferior humans, but as a multi-faceted society, whose way of life represented an imminent risk to Rome's very survival. For the philosopher emperor, the war against the Norse essentially meant the struggle of civilization against barbarism, an inevitable warfare which could not be postponed. Even the Empire's territorial expansion project was partially motivated by the stoic notion that the world as a whole is a city without borders. It is not possible to dissociate the successful emperor's personality from the image of the wise stoic. Consequently, the austerity of stoicism made Marcus Aurelius a man with a extraordinary strength, a man who devoted himself entirely, in body and soul, to Roman public fides.

\section{Bibliography}

Birley, Anthony. Marcus Aurelius: a biography. London: Routledge, 1987.

Cicero. De Officiis. Translation by Walter Miller. New York: The Loeb Classical Library, 1913. https://doi.org/10.4159/ DLCL.marcus tullius cicero-de officiis.1913

Diogenes Laertius. Lives of eminent philosophers. Translation by Robert Hicks. London: The Loeb Classical Library, 1925. https://doi.org/10.4159/DLCL.diogenes laertius-lives eminent philosophers book vi chapter 2 diogenes. 1925

Epictetus. Epicteti Dissertationes ab Arriano digestae. Heinrich Schenkl. Editor. Leipzig. B. G. Teubner. 1916.

Epictetus. The Enchiridion. Translated by Thomas Higginson. Boston: Little, Brown, and Company, 1891.

Fontaine, Françoise. Marc Aurèle. Paris: Editions de Fallois, 1991.

Gagin, François. "El yo y los otros: la estilización de sí y de las figuras al margen de la filosofía en las meditaciones de Marco Aurelio". Diálogos 51, no. 105 (2020): 93-102.

Hadot, Pierre. Exercices Spirituels et Philosophie Antique. Paris: Éditions Albin Michel, 2002.

Hadot, Pierre. La Citadelle Intérieure: Introduction aux Pensées de Marc Aurèle. Paris: Librairie Arthème Fayard, 1992.

Lombardini, John. "Stoicism and the virtue of toleration". History of Political Thought 36, no. 4 (2015): 643-669.

Marcus Aurelius. M. Antonius Imperator Ad Se Ipsum. Jan Hendrik Leopold. in aedibus B. G. Teubneri. Leipzig. 1908.

Marcus Aurelius. Meditations. Translation by Arthur Farquharson. London: Collector's Library, 2011.

Nascimento, Savaget and Matos, Andityas. Stoicism and Roman law: the rescripts of emperor Marcus Aurelius on family law and the law of liberty. Athens: ATINER'S Conference Paper Series (2014): 1-14.

Noyen, Paul. "Marcus Aurelius, the greatest practician of stoicism". In: L’antiquité classique, Tome 24, fasc. 2 (1955): 372- 383. https://doi.org/10.3406/antiq.1955.3266

Grimal, Pierre. Marc Aurèle. Paris: Libraire Arthème Fayard, 1991.

Wolf, Edita. "Marcus Aurelius and non-tragic living". Graeco-Latina Brunensia 20, no. 2 (2015): 189-198.

33 Marcus Aurelius, Meditations, 48.

34 Cf. Grimal, Marc Aurèle, Chapter 2. 